\title{
Analysis of heart rate variability in corn snakes (Pantherophis guttatus)
}

\author{
Análise dla variabilidade da frequência cardíaca em serpentes Pantherophis guttatus \\ Análisis de la variabilidad de la frecuencia cardíaca en serpientes Pantherophis guttatus
}

Received: 08/24/2021 | Reviewed: 08/29/2021 | Accept: 08/30/2021 | Published: 09/01/2021

\author{
Antonio Gomes da Silva Neto \\ ORCID: https://orcid.org/0000-0003-0733-3097 \\ Universidade Brasil, Brazil \\ Faculdade Uninassau, Brazil \\ E-mail: antonniogomess@hotmail.com \\ Daniel Souza Ferreira Magalhães \\ ORCID: https://orcid.org/0000-0002-3761-1927 \\ Universidade Brasil, Brazil \\ E-mail: daniel.magalhaes@universidadebrasil.edu.br \\ Raduan Hage \\ ORCID: https://orcid.org/0000-0002-9858-4774 \\ Universidade do Vale do Paraíba, Brazil \\ E-mail: raduanhage@gmail.com \\ Laurita dos Santos \\ ORCID: https://orcid.org/0000-0002-6363-6837 \\ Universidade Brasil, Brazil \\ E-mail: lauritas9@gmail.com \\ José Carlos Cogo \\ ORCID: https://orcid.org/0000-0001-8712-5022 \\ Universidade Brasil, Brazil \\ E-mail: jccogo@gmail.com
}

\begin{abstract}
The assessment of heart rate variability (HRV) by linear methods in conjunction with Poincaré plots can be useful for evaluating cardiac regulation by the autonomic nervous system and for the diagnosis and prognosis of heart disease in snakes. In this report, we describe an analysis of HRV in conscious adult corn snakes Pantherophis guttatus ( $P$. guttatus). The electrocardiogram (ECG) parameters were determined in adult corn snakes ( 8 females, 13 males) and used for HRV analysis, and the RR interval was analyzed by linear methods in the time and frequency domains. There was no sex-related difference in heart rate. However, significant differences were seen in the duration of the P, PR, and T waves and QRS complex; there was no difference in the QT interval. The values for the RR interval varied by $15.3 \%$ and $18.8 \%$ in male and female snakes, respectively, and there was considerable variation in the values for the high and low frequency domains. The changes in the time domain were attributed to regulation by the parasympathetic branch of the autonomic nervous system, in agreement with variations in the high and low frequency domains. The values for standard deviations 1 and 2 in Poincaré plots, as well as the values of the frequency domain, provide useful parameters for future studies of cardiac function in P. guttatus.
\end{abstract}

Keywords: Autonomic regulation; Electrocardiogram; Heart rate variability; Poincaré plot; Pantherophis guttatus.

\section{Resumo}

A avaliação da variabilidade da frequência cardíaca (VFC) por métodos lineares em conjunto com gráficos de Poincaré pode ser útil para avaliar a regulação cardíaca pelo sistema nervoso autônomo e para o diagnóstico e prognóstico de doenças cardíacas em serpentes. Neste trabalho, descrevemos uma análise da VFC em cobras do milho adultas conscientes Pantherophis guttatus ( $P$. guttatus). Os parâmetros do eletrocardiograma (ECG) foram determinados em serpentes do milho adultas ( 8 mulheres, 13 homens) e utilizados para análise da VFC, e o intervalo RR foi analisado por métodos lineares nos domínios do tempo e da frequência. Não houve diferença relacionada ao sexo na frequência cardíaca, no entanto, diferenças significativas foram observadas na duração das ondas $\mathrm{P}, \mathrm{PR}$ e T e do complexo QRS; não houve diferença no intervalo QT. Os valores do intervalo RR variaram 15,3\% e 18,8\% em serpentes macho e fêmea, respectivamente, e houve variação considerável nos valores para os domínios de alta e baixa frequência. As mudanças no domínio do tempo foram atribuídas à regulação pelo ramo parassimpático do sistema nervoso autônomo, de acordo com as variações nos domínios de alta e baixa frequência. Os valores dos desvios padrão 1 e 2 em gráficos de Poincaré, bem como os valores do domínio da frequência, fornecem parâmetros úteis para estudos futuros da função cardíaca em $P$. guttatus.

Palavras-chave: Regulação autonômica; Eletrocardiograma; Variabilidade da frequência cardíaca; Curva de Poincaré; Pantherophis guttatus. 


\section{Resumen}

La evaluación de la variabilidad de la frecuencia cardíaca (VFC) por métodos lineales junto con los gráficos de Poincaré puede ser útil para evaluar la regulación cardíaca del sistema nervioso autónomo y para el diagnóstico y pronóstico de enfermedades cardíacas en serpientes. En este trabajo, describimos un análisis de la VFC en serpientes de maíz adultas conscientes Pantherophis guttatus (P. guttatus). Los parámetros del electrocardiograma (ECG) se determinaron en serpientes de maíz adultas ( 8 hembras, 13 machos) y se utilizaron para el análisis de la VFC, y el intervalo RR se analizó por métodos lineales en los dominios de tiempo y frecuencia. No hubo diferencias relacionadas con el sexo en la frecuencia cardíaca, sin embargo, se observaron diferencias significativas en la duración de las ondas P, PR y T y el complejo QRS; no hubo diferencia en el intervalo QT. Los valores para el intervalo RR variaron en un $15,3 \%$ y un $18,8 \%$ en serpientes macho y hembra, respectivamente, y hubo una variación considerable en los valores para los dominios de alta y baja frecuencia. Los cambios en el dominio del tiempo se atribuyeron a la regulación de la rama parasimpática del sistema nervioso autónomo, de acuerdo con las variaciones en los dominios de alta y baja frecuencia. Los valores de las desviaciones estándar 1 y 2 en los gráficos de Poincaré, así como los valores del dominio de la frecuencia, proporcionan parámetros útiles para futuros estudios de la función cardíaca en $P$. guttatus.

Palabras clave: Regulación autonómica; Electrocardiograma; Variabilidad de la frecuencia cardíaca; Diagrama de Poincaré; Pantherophis guttatus.

\section{Introduction}

The electrocardiogram (ECG) is a reliable and widely used means of recording cardiac signals in many animals. The ECG can be represented graphically on a tachogram that shows the sequence of RR intervals. The RR interval is one of the most widely employed indices for studying heart rate variability (HRV) and can be used to assess fluctuations in cardiac regulation by the autonomic nervous system (Freitas, 2000). HRV describes oscillations of consecutive RR intervals. Clinically, HRV analysis can be used to detect changes in cardiac function and neuronal activity that may be indicative of the animal's general health, with a high HRV indicating a well-regulated system and a low or reduced HRV indicating potential health problems; such analyses can improve the interpretation and management of heart disease in reptiles (Veras and González, 1999; Veras et al., 2000; Wang et al. 2003; Cruz and Junkes, 2008; La Rovere et al., 2012; Gemer, 2016; Shaffer and Ginsberg, 2017).

HRV analysis generally involves the use of linear methods (Vanderlei et al., 2009) as a function of time or frequency (Rocha et al., 2005). The analysis as a function of time is directly related to the RR interval and involves determination of the standard derivation of all the NN intervals (SDNN), the standard derivation of the average NN interval (SDANN), and the root mean square of successive differences (RMSSD) between heartbeats (Vanderlei et al., 2009). On the other hand, HRV analysis as a function of frequency involves the application of mathematical equations to fluctuations in the RR that can be used to generate the geometric models required for Poincare graph construction. For this, the data points are plotted in the Cartesian plane along a line that forms two indices, with the instantaneous variability being given by standard deviation 1 (SD1) and the long-term continuous variability by standard deviation 2 (SD2). The variations associated with the SD1 and SD2 axes reflect variations in regulation by the autonomic nervous system (Task Force, 1996; Hoshi and Armstrong, 2013).

The ease with which the ECG can be recorded makes this technique particularly useful for studying cardiac function in snakes and for monitoring the health status of these animals in a clinical setting, particularly in relation to the identification and characterization of cardiovascular and non-cardiovascular pathologies. Several studies have examined the ECG parameters of snakes such as Boa constrictor (boa constrictor) (Valentinuzzi et al., 1970), Spilotes pullatus (tropical chicken snake or yellow rat snake) (Kik and Mitchell, 2005; Cruz and Junkes, 2008) and Crotalus durissus (tropical rattlesnake) (Stuginski et al., 2011).

P. guttatus (Linnaeus, 1766), commonly known as the red or eastern corn snake, is a non-venomous North American snake belonging to the family Colubridae. Corn snakes readily adapt to captivity and for this reason are widely kept as pets (Conant and Collins, 1998; Bird et al. 2015). However, there is little information on the cardiovascular physiology of this 
species. Lewis et al. (2020) examined the cardiac electrical activity of $P$. guttatus and described the various waves (S, P and R) and intervals (PR, RT and TP) of the ECG in these snakes. These authors noted that the TP interval was particularly useful for evaluating stress in these snakes and that there were important differences when compared with the mammalian ECG.

In this study, we recorded the ECG from conscious corn snakes and used a combination of linear methods to analyze HRV. The data obtained provide useful information on the cardiac parameters in P. gutattus and HRV analysis could be a potentially helpful approach for diagnosing and monitoring cardiac and neural diseases in this species.

\section{Methodology}

\subsection{Study}

This is an exploratory experimental study, with a qualitative and quantitative approach. The experimental method provides manipulation of independent variables allowing the accumulation of information about the studied phenomenon and easy sampling (Gil, 2010).

\subsection{Animals}

Corn snakes ( $P$. gutattus; 8 females and 13 males) were obtained from the Serpentário do Centro de Estudos da Natureza (CEN, Secretário do Meio Ambiente permit SMA 15.380/2012) at the Universidade do Vale do Paraíba (UNIVAP, São José dos Campos, SP, Brazil) and were housed individually at room temperature in clear plastic boxes with ventilation holes. The snakes had free access to water and were fed 1-2 mice every 15 days. Immediately prior to use, the snakes were weighed, and the snout-vent (cloaca) length and tail length were recorded. The experiments described here were approved by the Committee for Ethics in Animal Use (CEUA/UNIVAP, protocol no. 01/CEUA/2015).

\subsection{Signal measurements}

Conscious (non-sedated) snakes were used since anesthesia may depress vagal and cardiac activity (Mullen, 1967). To record the ECG, the snakes were restrained individually with the ventral surface downwards in a clear plastic tube, with the cephalic one-third to half of the body inserted into the tube (Figure 1). Most work on heart rate in snakes is carried out under resting conditions and with anesthetized animals, a factor that can interfere with a full understanding of this animals (Lily white et al., 1999; Stunginsk; Fernandes; Grego, 2011). 
Figure 1. Procedure for restraining $P$. guttatus for ECG measurements. The anterior region of the snake was inserted into a clear plastic tube prior to attaching the ECG electrodes.

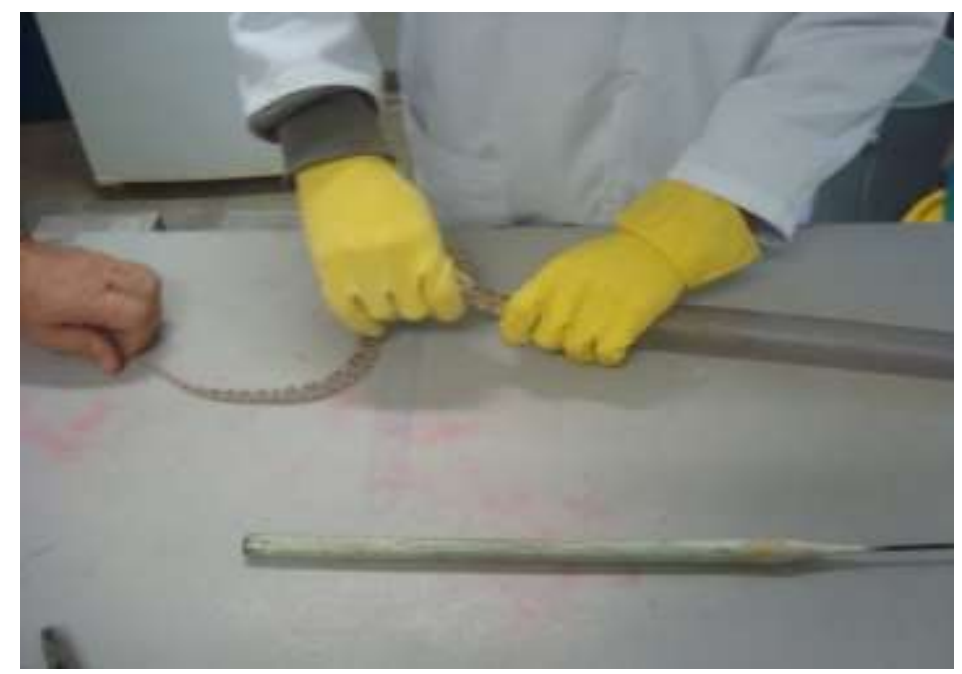

Source: Authors.

Four clip electrodes were placed laterally along the body: two were positioned cranially to the heart and two caudally, all equidistant from this organ. The position of the heart was determined by Doppler imaging (Medmega Doppler imager, Franca, SP, Brazil).

The ECG was recorded and analyzed using a computerized electrocardiograph with appropriate acquisition software (ECG PCV Acquisition Module 6.2, Tecnologia Eletrônica Brasileira - TEB, São Paulo, SP, Brazil). The use of non-sedated snakes meant that the duration of the recordings varied considerably, depending on the animal's behavior. However, in all cases, the ECG was recorded for up to $2 \mathrm{~min}$. For RR interval analysis, the duration of the interval (in milliseconds, ms) was determined from at least 37 ECG traces, with an average of 46 intervals for each snake. HRV was assessed using linear methods, as described below.

\subsection{Determination of the HRV index}

Time domain indices for RR interval time series were calculated based on the standard deviation of all the NN intervals (SDNN), the standard deviation of the average NN interval (SDANN) and the root mean square of successive differences (RMSSD) between heartbeats, all expressed in ms (Vanderlei et al. 2009). The time domain intervals can be represented by geometric methods based on the triangulation index of the Poincaré plot that determines the dispersion of $\mathrm{RR}_{\mathrm{n}}$ vs $R_{n+1}$, where $R R$ represents the time elapsed between two consecutive peaks $(n$ and $n+1)$. The horizontal axis of the histogram represents the length of the intervals and the vertical axis indicates the frequency at which these intervals occur; these two parameters $\left(R_{n}\right.$ and $\left.R_{n+1}\right)$ are insensitive to artifacts as they are outside the triangle. Subsequent analysis of the $R R$ interval series allowed application of the first return map and the estimation of SD1 and SD2 associated with the standard deviation of the short and long-term RR intervals.

For the frequency domain, a non-parametric method based on the Fourier transformer algorithm, was used to decompose sequential series of RR intervals into different amplitudes and frequencies, thereby obtaining ultralow frequency $(<0.003 \mathrm{~Hz}$ ), very low frequency (VLF, 0.003-0.04 Hz), low frequency (LF, related primarily to the sympathetic system; $0.041-0.15 \mathrm{~Hz}$ ) and high frequency (HF, related primarily to the parasympathetic system; 0.151-0.4 Hz) data. The LF/HF ratio provided another means of assessing the balance between the sympathetic and parasympathetic systems (Armelin et al. 2019, Campbell et al. 2006; Vanderlei et al. 2009). 
All data analyses were done using Kubios ${ }^{\circledR}$ (Kuopio, Finland), a widely used free software for HRV analysis.

\subsection{Statistical analysis}

The results were expressed as the mean $\pm \mathrm{SD}$. The data were initially screened using the Kolmogorov-Smirnov test which showed that they did not follow a normal distribution. Subsequent statistical comparisons between males and females were therefore done using the Mann-Whitney non-parametric test, with $\mathrm{p}<0.05$ indicating significance. All statistical analyses were done using Prism v.5.0 (GraphPad Inc., San Diego, CA, USA).

\section{Results}

\subsection{Biometric parameters}

Table 1 shows the biometric parameters (body weight, snout-vent/cloaca length and tail length) for the snakes used in this study, with males being significantly heavier and longer than females.

Table 1. Body weight, snout-vent length and tail length in male and female corn snakes ( $P$. gutattus). Body weight and lengths were measured to the nearest $0.1 \mathrm{~g}$ and $0.1 \mathrm{~cm}$, respectively. The values represent the mean $\pm \mathrm{SD}$ for the number of snakes shown.

\begin{tabular}{lccc}
\cline { 2 - 4 } & Females $(\mathrm{n}=8)$ & Males $(\mathrm{n}=13)$ & $\mathrm{p}$ \\
\hline Body weight $(\mathrm{g})$ & $255.1 \pm 68.0$ & $437.2 \pm 115.7$ & $<0.005$ \\
Length $(\mathrm{cm})$ & & & \\
$\quad$ Snout-vent & $94.9 \pm 9.8$ & $107.9 \pm 9.0$ & 0.0064 \\
Tail & $15.0 \pm 1.7$ & $16.7 \pm 3.7$ & 0.057 \\
Snout-tail & $109.9 \pm 11.2$ & $124.4 \pm 8.1$ & 0.002 \\
\hline
\end{tabular}

Source: Authors.

\subsection{Heart rate analysis}

Figure 2 shows a representative recording of the ECG used to determine the heart rate and to assess the QRS complex and calculate the RR interval. Table 2 shows the heart rate and ECG parameters for male and female corn snakes; there was no significant sex-related difference in heart rate. In contrast, there were significant sex-related differences in the duration of the $\mathrm{P}, \mathrm{PR}$, and $\mathrm{T}$ waves and the QRS complex, but no difference in the QT interval. There were also significant sex-related differences in the RR interval $(\mathrm{p}<0.001)$, with this interval varying by $15.3 \%\left(\mathrm{r}^{2}=0.104\right)$ and $18.8 \%\left(\mathrm{r}^{2}=0.0004\right)$ for males and females, respectively. 
Figure 2. Representative ECG recording from a corn snake ( $P$. guttatus) showing the QRS complex, RR interval and $\mathrm{P}$ wave. The ECG was recorded using ECG-PCVet software with the snake at rest at $25^{\circ} \mathrm{C}$.

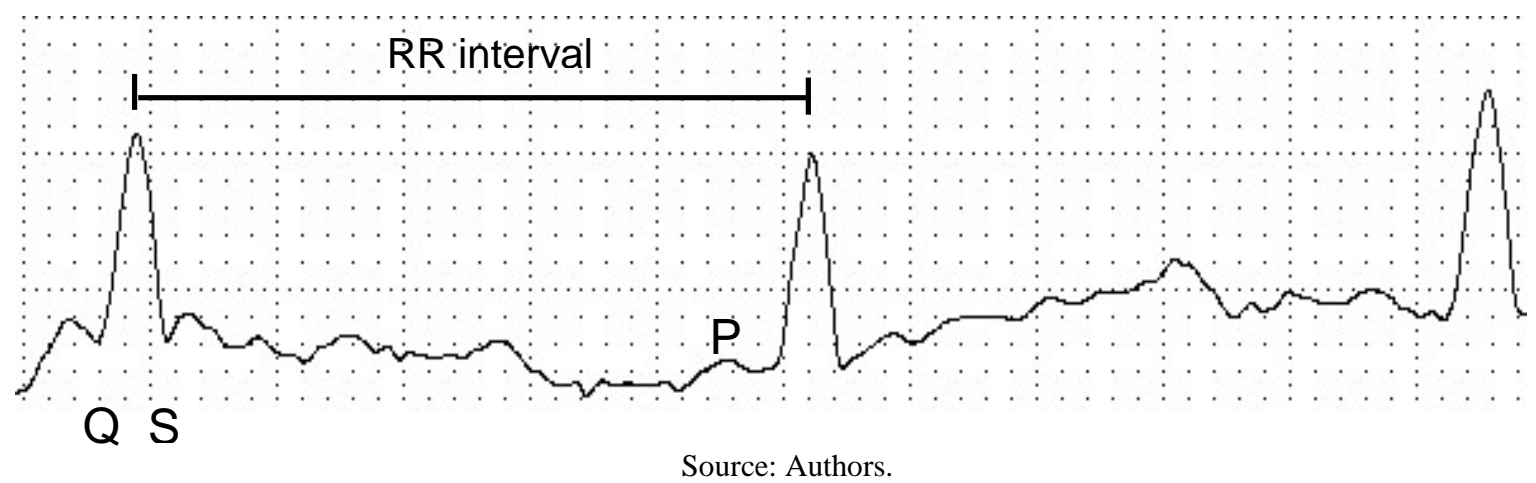

Table 2. Heart rate and ECG parameters in male and female corn snakes (P. gutattus). The data represent the mean \pm SD of the number of snakes indicated. bpm - beats per minute.

\begin{tabular}{lccc}
\hline & \multicolumn{2}{c}{ Sex } & \\
\cline { 2 - 3 } Parameter & Male $(\mathrm{n}=13)$ & Female $(\mathrm{n}=8)$ & $\mathrm{p}$ \\
\hline Heart rate $(\mathrm{bpm})$ & $53 \pm 8$ & $50 \pm 9$ & 0.5511 \\
ECG parameter $(\mathrm{ms})$ & & & \\
$\quad$ P wave & $87.7 \pm 17.6$ & $116.5 \pm 19.2$ & $<0.05$ \\
PR interval & $273.7 \pm 32.3$ & $344.7 \pm 67.0$ & 0.0047 \\
QRS wave & $160.7 \pm 12.4$ & $147.0 \pm 17.8$ & 0.0459 \\
T wave & $134.4 \pm 30.5$ & $170.9 \pm 47.4$ & $<0.05$ \\
QT interval & $715.4 \pm 145.1$ & $769.3 \pm 176.0$ & 0.5393 \\
\hline & Source: Authors. &
\end{tabular}

\subsection{Time domain evaluation}

Female snakes had a significantly greater RR interval and RMSSD than males, but a lower heart rate and SDNN (Table 3).

Poincaré plot analysis indicated low variability among the RR intervals, with a consequent low distribution in the graph. The comet-shaped graph (Figure 3) showed low values for males in SD1 (87.8 \pm 82.0$)$ and SD2 (87.6 \pm 68.7$)$ and for females in SD1 $(87.6 \pm 68.7)$ and SD2 $(86.7 \pm 77.8)$. The SD1/SD2 ratio of 0.934 indicated there was no significant difference between the sexes and a Mann-Whitney test comparing males and females confirmed there was no significant difference between them $(\mathrm{p}=0.0546)$. The SD1 values in both groups indicated the presence of arrhythmias and increased vagal nerve activity that pointed to increased activity of the parasympathetic system.

Table 3. Parameters for cardiac variability. $* \mathrm{HR}-$ heart rate (bpm - beats per min), ***RMSSD - root mean square of successive differences between heartbeats, $* * \mathrm{RR}-\mathrm{RR}$ interval, $* * * * \mathrm{SDNN}-$ standard deviation of all the NN intervals.

\begin{tabular}{lccc} 
& Male & Female & $\mathrm{p}$ \\
\hline HR* $(\mathrm{bpm})$ & $53 \pm 8$ & $50 \pm 9$ & 0.5511 \\
$\mathrm{RR} * *(\mathrm{~ms})$ & $1150.1 \pm 148.5$ & $1192.7 \pm 149$ & $<0.0001$ \\
$\mathrm{RMSSD} * * *(\mathrm{~ms})$ & $121.7 \pm 114.2$ & $137.8 \pm 290.9$ & 0.0061 \\
SDNN****(ms) & $88.2 \pm 74.2$ & $25.6 \pm 4.1$ & 0.0058 \\
\hline
\end{tabular}

Source: Authors. 
Figure 3. Poincaré plots of the RR intervals for male (A) and female (B) corn snakes (P. guttatus). The plots were analyzed based on the procedure of elipse adjustment, with SD1 and SD2 corresponding to the perpendicular standard deviations along the line of identity, where $R_{n}$ and $R_{n+1}$ correspond to adjacent consecutive RR intervals. Each point represents the means of RR intervals for males and females.

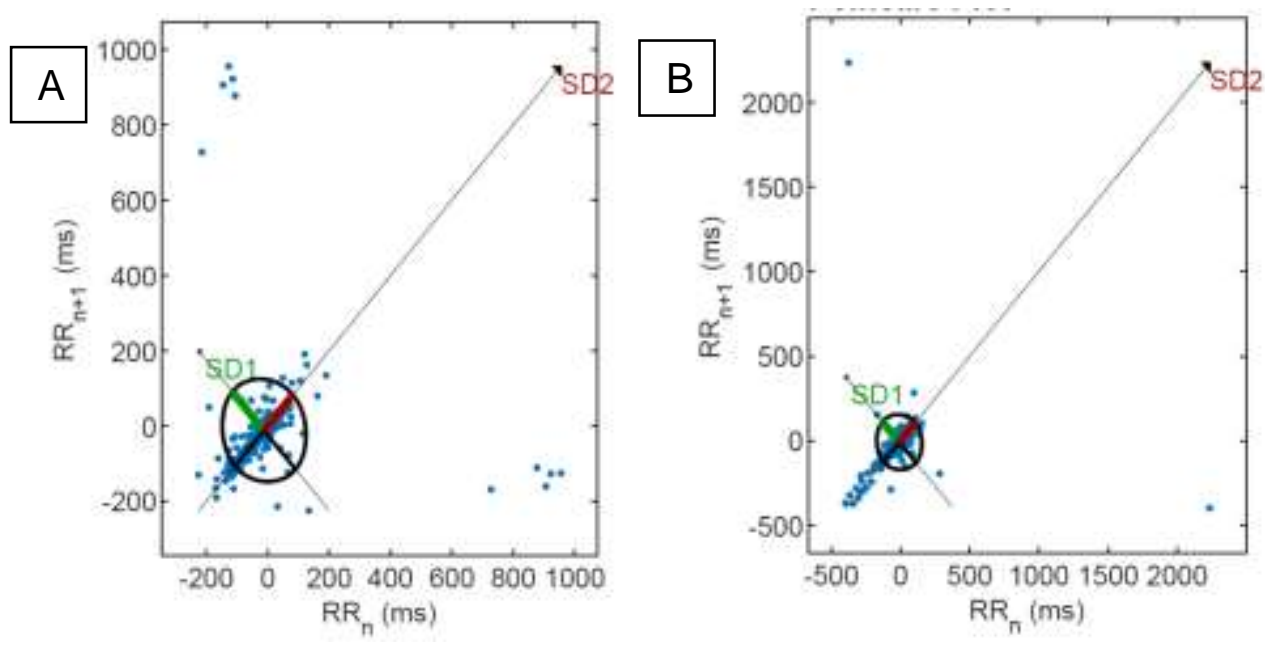

Source: Authors.

\subsection{Frequency domain evaluation}

The frequencies ranged from 0.0001 to $0.40 \mathrm{~Hz}$, with high frequency (HF) bands showing the highest incidence, a situation that reflected vagal nerve activity on the heart and respiration; there was no difference between males and females (Table 4). The low frequency (LF) bands showed peaks of $0.070 \mathrm{~Hz}$ and $0.115 \mathrm{~Hz}$ for males and females, respectively ( $\mathrm{p}=$ 0.0132). This difference probably reflected interaction between the vagus nerve and the sympathetic system. Based on the peak values for the LF and HF bands, the corresponding LF/HF ratios were 0.819 and 0.302 for male and female snakes, respectively (Figure 3).

Table 4. Frequency analysis of the RR interval in male and female corn snakes (P. guttatus). The values are the mean \pm SD.

\begin{tabular}{lccc}
\cline { 2 - 4 } & \multicolumn{3}{c}{ Peak frequency $(\mathrm{Hz})$} \\
\hline Parameter & Male $(\mathrm{n}=13)$ & Female $(\mathrm{n}=8)$ & $\mathrm{p}$ \\
\hline Very low frequency (VLF) & $0.029 \pm 0.015$ & $0.029 \pm 0.017$ & 0.552 \\
Low frequency (LF) & $0.070 \pm 0.036$ & $0.115 \pm 0.021$ & 0.0132 \\
High frequency (HF) & $0.283 \pm 0.084$ & $0.203 \pm 0.057$ & 0.3601 \\
\hline
\end{tabular}

Source: Authors.

\section{Discussion}

The morphometric data for the snakes used in this study were similar to those reported by Pess et al. (2016) for this species, with males being larger than females. Heart rate in snakes can be influenced by a variety of factors, including body temperature, metabolic activity, gas exchange, blood $\mathrm{pH}$, body posture and reflex regulation of blood pressure by neurohumoral excitatory (adrenergic) and inhibitory (cholinergic) mechanisms (Lillywhite et al., 1999, 2012; Taylor et al., 2014). The controlled conditions under which the measurements were made in this study probably helped to minimize the influence of external (environmental) factors on HRV. 
As shown here, there was no significant difference in heart rate between male and female snakes. This finding agrees with that of Lewis et al. (2020), who also reported no sex-related differences in heart rate in this species. In contrast, there were significant sex-related differences in several ECG parameters, including the P and T waves, QRS complex and PR interval. Valentinuzzi et al., (1970) observed considerable variation in the T wave amplitude and duration over several days in snakes, although no immediate apparent cause of such variations was identified. The values for the ECG parameters in $P$. guttatus were lower than those for other species such as Boa constrictor (Conceição et al., 2014; Armelin et al. 2019), Lampropeltis getuhts (Valentinuzzi et al., 1970) and Eunectes murinus (Strussmann, and Sazima,1991), but similar to those reported for Spilotes pullatus (Cruz and Junkes, 2008) and Crotalus durissus (Stuginski et al., 2011).

Time analysis indicated a significant sex-related difference in the RR interval, with females having a longer interval than males. This difference may reflect variations in the level of autonomic nervous system activity between the two sexes. The relationship between SDNN values and autonomic nervous system activity is well known in mammals, especially humans, with the SDNN providing an indication of the activity of the sympathetic nervous system (Vanderlei et al., 2009; Lopes et al., 2013; Sá et al., 2013). Nilson (2010) reported similarities in the organization of the autonomic nervous system between snakes and mammals, but it is unclear to what extent this would influence the relationship between SDNN and this system in these reptiles.

In the Poincaré plot analysis, the values for SD1 and SD2 and the SD1/SD2 ratio were not significantly different between males and females. Stress potentially caused to the snakes during ECG measurement could have activated the sympathetic system, thereby reducing the RR interval and increasing heart rate, as also observed for other snake species, e.g., Spilotes pullatus (Cruz and Junkes, 2008). SD1 is associated with the short-term modulation of heart rate variability that is influenced by the parasympathetic nervous system, whereas SD2 is associated with the long-term modulation of heart rate variability that is influenced by the sympathetic nervous system (Roy and Ghatak, 2013). The SD1 and SD2 values for $P$. guttatus indicated cardiac regulation by the sympathetic and parasympathetic systems. The Poincaré plot indicated activation of the autonomic nervous system, with an increase in parasympathetic modulation of the sinoatrial node. The influence of the parasympathetic nervous system on cardiac responses is well known in mammals such as rats (Nijsen et al., 1998).

Comparative studies based on the analysis of Poincaré plots have shown influence of the sympathetic and parasympathetic branches of the autonomic nervous system on HRV in healthy and diseased individuals (Vanderlei et al., 2010). Fluctuations in band frequencies are modulated by the autonomic nervous system. In mammals, in which fluctuations are widespread, HF variations are related primarily to activity of the parasympathetic nervous system, whereas LF variations are related to the activity of both branches (sympathetic and parasympathetic) of the autonomic nervous system (Malik and Camm, 1995).

The LF and HF values and the LF/HF ratio were similar to those reported for Boa constrictor, in which the main LF peak occurred between 0.0 and $0.1 \mathrm{~Hz}$ and a smaller HF peak between $0.1 \mathrm{~Hz}$ and $0.2 \mathrm{~Hz}$ (Armelin et al., 2019). The peaks in each frequency range can vary in relation to the respiratory rate, as shown for the South American rattlesnake Crotalus durissus terrificus (Campbell et al., 2006). Cardiorespiratory interactions, including respiratory sinus arrhythmia, occur in a variety of vertebrates and are mediated by the parasympathetic system that modulates the RR interval (Sanches et al., 2019). Although not significant, variation in the HF wave seen here in P. gutattus, with a corresponding reduction in the LF/HF ratio, suggested a possible decrease in vagal tone and its sympathetic modulation. The anatomical organization of the reptilian heart predisposes these animals to reduced vagal tone since venous blood flows through the ventricles to the lungs (right-left shunt) followed by pumping to the general circulation during systole (Germer, 2016). Campbell et al. (2006) noted that, in contrast to mammals, rattlesnakes (C. d. terrificus) simultaneously showed high and low frequency spectra. 
A variety of environmental stimuli can be stressful to snakes. Cruz and Junkes (2008) noted that exposure of the snake Spilotes pullatus to stress resulted in stimulation of the vagus nerve and an increase in the RR interval, leading to bradycardia. In addition, the animal's position during ECG recording, e.g., whether in a horizontal or inclined position, can influence the level of stress and consequently affect the accuracy with which the vectors are determined (Armelin et al., 2019). These studies suggest that a detailed analysis of the mechanisms of cardiac regulation in a given species can improve our understanding of its adaptations to its natural habitat, whether terrestrial, aerial or aquatic (Shoemaker and Zandvliet, 2005).

Despite anatomical variations in heart structure and organization, reptilian cardiac tissue responds to adrenergic and cholinergic stimulation in a manner similar to mammalian heart (Arita et al., 1967; Liu et al., 2014; Jensen et al., 2017). Compared to mammals, ectothermic animals show slower atrioventricular conduction, primarily because of poorly developed myocytes, the presence of considerable connective tissue, and a lower overall tissue excitability caused by a reduced number (density) of sodium channels (Jensen et al., 2012, 2014; Temple et al., 2013). In this context, a greater understanding of the cardiac physiology of snakes may be gained by HRV analysis, as described here.

\section{Conclusion}

Measurement of the ECG and RR interval in P. guttatus showed that these snakes have a heart rate of $\sim 50-55 \mathrm{bpm}$. However, analysis of the ECG alone is insufficient for an adequate assessment of cardiac function; a comprehensive evaluation can only be achieved with HRV analysis. Even with the electrocardiographic variations, the signals show consistency in the $\mathrm{P}$ wave repolarization and in the QSR complex. As shown here, HRV analysis in relation to time and frequency can be useful for evaluating the potential autonomic regulation of such variability. The sex-related differences observed for several parameters most likely reflected true physiological differences rather than being caused by any underlying pathology. The values for SD1 and SD2, and the findings for the frequency distributions (especially for LF, which has been widely used in other studies) provide a useful basis for future studies of $P$. guttatus and for comparative studies involving other snake species.

The present study presents a particularity about the reading of electrocardiographic signals, as in previous studies, animals are subjected to restraints through anesthesia, thus the data provide information about the cardiac system of $P$. guttatus without the use of chemical containment.

Given the data obtained in this research, it is indicated that further research be carried out with a greater number of individuals and with different types of snakes, as well as studies on the action of heart blockers on heart rate variability.

\section{Acknowledgments}

This study was financed in part by the Coordenação de Aperfeiçoamento de Pessoal de Nível Superior (CAPES, Finance code 001).

\section{References}

Arita, M., Saeki, K., Tanoue, M., Fukushima, I. \& Ito, M. (1967) Effects of catecholamines, propranolol, acetylcholine and ouabain on the transmembrane action potentials and contractility of the isolated venae cavae proximal to the heart of the rabbit. Jpn J Physiol. 17(2):158-73.

Armelin, V.A., Braga, V. H. S., Guagnoni, J. N., Crestani, A. M., Abe, A. S. \& Florindo, L. H. (2019) Autonomic control of cardiovascular adjustments associated with orthostasis in the scansorial snake Boa constrictor. J Exp Biol. 222:jeb197848.

Bird, W. M., Peak, P. \& Baxley, D. L. (2015) Natural history and meristics of an allopatric population of red cornsnakes, Pantherophis guttatus (Linnaeus, 1766) in central Kentucky, USA. J North Am Herpetol. (1):6-11.

Campbell, H. A., Leite, C. A. C., Wang, T., Skals, M., Abe, A. S., Egginton, S., Rantin, F. T., Bishop, C. M. \& Taylor, E. W. (2006) Evidence for a respiratory component, similar to mammalian respiratory sinus arrhythmia, in the heart rate variability signal from the rattlesnake, Crotalus durissus terrificus. J Exp Biol. 209:2628-36. 
Conant, R. \& Collins, T. J. (1998) A field guide to the amphibians and reptiles of Eastern and Central North America. $3^{\text {rd }}$ ed. Boston:Houghton Mifflin Co.

Conceição, M. E. B. A. M., Monteiro, F. O. B., Andrade, R. S. \& Melchert, A. (2014) Effect of biometric variables on two-dimensional echocardiographic measurements in the red-tailed boa (Boa constrictor constrictor). J Zoo Wildl Med. 45(3):672-77.

Cruz, J. G. P. \& Junkes, L. (2008) Controle autonômico da frequência cardíaca em Spilotes pullatus (Colubridae) como determinante das respostas de medo. Arq Bras Med Vet Zootec. 60(6):1468-71.

Freitas, A. F. (2000) Sistema nervoso autônomo e aparelho cardiovascular: um paradigma de auto-organização, complexidade e caos. Rev Port Cardiol. 19:161-91.

Gil, A. C. (2010) Como elaborar projetos de pesquisa. 4. ed. São Paulo: Atlas.

Gemer, C. M. (2016) Eletrocardiograma, movimento contrátil cardíaco e frequência cardíaca da lagartixa, Hemidactylus mabouia (Moreau de Jonnès, 1818). Dissertação de Mestrado, Faculdade de Engenharia Elétrica e de Computação, Universidade Estadual de Campinas (UNICAMP).

Hoshi, T. \& Armstrong, C. M. (2013) C-Type inactivation of voltage-gated K+ channels: pore constriction or dilation? J Gen Physiol. 141(2):151-60.

Jensen, B., Boukens, B. J. D., Postma, A. V., Gunst, Q. D., van den Hoff, M. J. B., Moorman, A. F. M., Wang, T. \& Christoffels, V. M. (2012) Identifying the evolutionary building blocks of the cardiac conduction system. PLoS One 7(9):e44231.

Jensen, B., Moorman, A. F. M. \& Wang, T. (2014) Structure and function of the hearts of lizards and snakes. Biol Rev Camb Philos Soc. 89(2):302-36.

Jensen, B., van den Berg, G, van den Deol, R., Oostra, R. J., Wang, T. \& Moorman, A. F. M. (2013) Development of the hearts of lizards and snakes and perspectives to cardiac evolution. PLoS One 8(6):e63651.

Jensen, D. D., Lieu, T., Halls, M. L., Veldhuis, N. A., Imlach, W. L., Mai, Q. N., Poole, D. P., Quach, T., Aurelio, L., Conner, J., Herenbrink, C. K., Barlow, N., Simpson, J. S., Scanlon, M. J., Graham, B., McCluskey, A., Robinson, P. J., Escriou, V., Nassini, R., Materazzi, S., Geppetti, P., Hicks, G. A., Christie, M. J., Porter, C. J. H., Canals, M. \& Bunnett, N. W. (2017) Neurokinin 1 receptor signaling in endosomes mediates sustained nociception and is a viable therapeutic target for prolonged pain relief. Sci Transl Med. May 31;9(392):eaal3447. doi: 10.1126/scitranslmed.aal3447. PMID: 28566424; PMCID: PMC6034632.

Kik, M. J. L. \& Mitchell, M. A. (2005) Reptile cardiology: a review of anatomy and physiology, diagnostic approaches and clinical disease. Semin Avian Exotic Pet Med. 14(1):52-60.

La Rovere, M. T., Pinna, G. D., Maestri, R., Barlera, S., Bernardinangeli, M., Veniani, M., Nicolosi, G. L., Marchioli, R., Tavazzi, L. \& GISSI-HF Investigators. (2012) Autonomic markers and cardiovascular and arrhythmic events in heart failure patients: still a place in prognostication? Data from the GISSI-HF trial. Eur J Heart Fail. 14(12):1410-19.

Lewis, M., Bouvard, J., Eatwell, K. \& Culshaw, G. (2020) Standardisation of electrocardiographic examination in corn snakes (Pantherophis guttatus). Vet Rec.186:e29.

Lillywhite, H. B., Albert, J. S., Sheehy, C. M. \& Seymour, R. S. (2012) Gravity and the evolution of cardiopulmonary morphology in snakes. Comp Biochem Physiol A Mol Integr Physiol. 161(2):230-42.

Lillywhite, H. B., Zippel, K. C. \& Farrell, A. P. (1999) Resting and maximal heart rates in ectothermic vertebrates. Comp Biochem Physiol A Mol Integr Physiol. 124(4):369-82.

Liu, R., Feng, H. Z. \& Jin, J. P. (2014) Physiological contractility of cardiomyocytes in the wall of mouse and rat azygos vein. Am J Physiol Cell Physiol. 306(7):697-704.

Lopes, P. F. F., Oliveira, M. I. B., André, S. M. S., Nascimento, D. L. A., Silva, C. S. S., Rebouças, G. M., Felipe, T. R., Albuquerque Filho, N. J. B. \& Medeiros, H. J. (2013) Aplicabilidade clínica da variabilidade da frequência cardíaca. Rev Neurocienc.21(2):600-03.

Malik, M. \& Camm, A. J. (1995) Heart rate variability. $1^{\text {st }}$ ed. Armonk:Futura.

Mullen, R. K. (1967) Comparative electrocardiography of the Squamata. Physiol Zool. 40(2):114-26.

Nijsen, M. J. M. A., Croiset, G., Diamant, M., Broekhoven, M. H., Wied, D. De. \& Wiegant, V. M. (1998) Vagal activation in novelty-induced tachycardia during the light phase in the rat. Physiol Behav. 63(2):233-9.

Nilson, S. (2010) Comparative anatomy of the autonomic nervous system. Autonom Neurosci. 165(1):3-9.

Pess, M., Neal, A., Müller, K., Schmidt, V., Truen, U., Leinecker, N. \& Marschang, R. (2016) Virus distribution and detection in corn snakes (Pantherophis guttatus) after experimental infection with three different ferlavirus strains. Vet Microbiol. 182:213-22

Rocha, R. M., Albuquerque, D. C. \& Albanesi Filho, F. M. (2005) Variabilidade da frequência cardíaca e ritmo circadiano em pacientes com angina estável. Rev Socerj. 18(5):429-42.

Roy, B. \& Ghatak, S. (2013) Métodos não-lineares para avaliar mudanças na variabilidade da frequência cardíaca em pacientes com diabetes tipo 2. Arq Bras Cardiol. 101(4):317-27.

Sá, J. C. F., Costa, E. C., Silva, E. \& Azevedo, G. D. (2013) Variabilidade da frequência cardíaca como método de avaliação do sistema nervoso autônomo na síndrome dos ovários policísticos. Rev Bras Ginecol Obstet. 35(9):421-6.

Shaffer, F. \& Ginsberg, J. P. (2017) An overview of heart rate variability metrics and norms. Front Public Health. 5:258. 
Research, Society and Development, v. 10, n. 11, e294101119781, 2021

(CC BY 4.0) | ISSN 2525-3409 | DOI: http://dx.doi.org/10.33448/rsd-v10i11.19781

Shoemaker, N. J. \& Zandvliet, M. M. J. M. (2005) Electrocardiograms in selected species. Semin Avian Exotic Pet Med. 14(1):26-33.

Stuginski, D. R., Fernandes, W. \& Grego, K. F. (2011) Parâmetros eletrocardiográficos de cascavéis (Crotalus durissus, Linnaeus, 1758) em cativeiro. Arch Vet Sci. 16(3):31-7.

Strussmann, C. \& Sazima, I. (1991) Predation on avian eggs by the boid snake, Eunectes notaeus. Herpetological Review 22: 118-120.

Task Force of the European Society of Cardiology and the North American Society of Pacing and Electrophysiology (1996) Heart rate variability. Standards of measurement, physiological interpretation, and clinical use. Eur Heart J. 17(5):354-81.

Taylor, E. W., Leite, C. A. C., Sartori, M. R., Wang, T., Abe, A. S. \& Crossley, D. A. (2014) The phylogeny and ontogeny of autonomic control of the heart and cardiorespiratory interactions in vertebrates. J Exp Biol. 217(5):690-703.

Temple, I. P., Inada, S., Dobrzynski, H. \& Boyett, M. R. (2013) Connexins and the atrioventricular node. Heart Rhyth. 10(2):297-304.

Valentinuzzi, M. E., Hoff, H. E. \& Geddes, M. E. (1970) Electrocardiogram of the snake: effect of vagal stimulation on the Q-T duration. J Electrocardiol. $3(1): 21-8$.

Vanderlei, L. C. M., Pastre, C. M., Hoshi, R. A., Carvalho, T. D., Godoy, M. F. (2009) Noções básicas de variabilidade da frequência cardíaca e sua aplicabilidade clínica. Rev Bras Cir Cardiovasc. 24(2):205-17.

Vanderlei, L. C. M., Pastre, C. M., Freitas Júnior, I. F. \& Godoy, M. F. (2010) Índices geométricos de variabilidade da frequência cardíaca em crianças obesas e eutróficas. Arq Bras Cardiol. 95(1):30-40.

Veras, L. \& González, J. G. (1999) Power spectral analysis of short-term RR interval and arterial blood pressure oscillations in the lizard, Gallotia galloti: effects of sympathetic blockade. J Exp Zool. 283(2):113-20.

Veras, L., González, J. G. \& Pereda, E. (2000) Relationship between cortical electrical and cardiac autonomic activities in the awake lizard, Gallotia galloti. J Exp Zool. 287(1):21-8.

Wang, T., Altimiras, J., Klein, W. \& Axelsson, M. (2003) Ventricular haemodynamics in Python molurus: separation of pulmonary and systemic pressures. $J$ Exp Biol. 206:4241-45. 